\section{Considerações Sobre o Câncer de Tiveóide na Infância}

A NeOPlasia Maligna da TiReóide em crianças é considerada rara. Dentre estes tumores, os mais comuns são os carcinomas derivados da célula folicular, denominados diferenciados (papilífero, folicular e suas variantes menos agressivas). $\mathrm{O}$ tumor medular e os pouco diferenciados (insular, Hürthle, tall cells, etc.) correspondem apenas a 5 a $10 \%$ do total.

$\mathrm{Na}$ casuística apresentada por Cardoso e colaboradores no artigo publicado nesta edição dos ABE\&M (1), vemos uma incidência de carcinoma medular de tireóide acima do observado na literatura em geral, talvez por apresentar uma casuística de apenas 15 casos. A evolução dos carcinomas medulares de tireóide é, em geral, mais rápida, sendo diferente da apresentada pelos tumores diferenciados derivados da célula folicular.

No seguimento dos tumores malignos da tireóide na infầncia, o que chama a atenção são as diferenças de comportamento dos tumores diferenciados entre crianças e adultos. Na faixa etária infantil, em geral são muito mais agressivos e com grande índice de metástases ao diagnóstico, como o observado no artigo em questão. Está indicada uma terapia mais radical: tireoidectomia total, esvaziamento cervical, quando necessário, e complementação com atividades elevadas de radioido. $\mathrm{O}$ artigo de Cardoso e cols. (1) mostra cinco pacientes nos quais a cirurgia inicial foi parcial e que tiveram que ser reoperados por recidiva tumoral, mostrando a importância de uma abordagem inicial mais agressiva. Vários estudos tentam explicar o motivo desta diferença: presença ou não de determinadas mutações, como as descritas no artigo.

Recentemente vem se estudando o gene BRAF presente no carcinoma papilífero do adulto, porém raro nos tumores que atingem a população infantil (2). Da mesma forma a presença de receptores IGF-1 nos tumores da infância poderia ser responsável, em parte, pela agressividade inicial apresentada (3). Apesar de toda essa agressividade, os tumores diferenciados têm uma excelente resposta ao tratamento cirúrgico complementado pela radioiodoterapia, proporcionando um longo período livre de doença, com raras recidivas e boa resposta terapêutica das metástases, em especial as pulmonares. No artigo em discussão (1), os pacientes reportados, além de apresentarem doença muito avançada ao diagnóstico, têm outras doenças associadas como linfoma de Hodgkin, MEN 2B e carcinoma medular, o que torna o prognóstico mais sombrio (4).

A relação entre o aparecimento do carcinoma papilífero com a exposição prévia à radiação ionizante é conhecida de longa data: na década de 50, o amplo uso do RX no tratamento da hipertrofia do timo, amígdalas, acne $\mathrm{e}$, mais recentemente, os acidentes nucleares e a radioterapia externa de outros tumores da infância, onde a região cervical é incluída no campo de irradiação. Com o aumento da sobrevida deste pacientes, o carcinoma de tireóide ocupa um lugar de destaque no surgimento de uma segunda neoplasia. Em geral os tumores originados de áreas irradiadas são mais agressivos (4).

A presença de linfonodo cervical pode ser a primeira manifestação do tumor nesta faixa etária. Nessa ocasião, é muito importante uma história clinica apurada, acompanhada de um exame físico minucioso. Muitas vezes, editorial

Rossana Corbo

\author{
Professora Adjunta do \\ Departamento de Radiologia, \\ Universidade Federal do Rio de \\ Janeiro (UFRJ). Mestre em \\ Endocrinologia (UFRJ) $e$ \\ Doutora em Medicina Nuclear \\ (UFRJ). Médica Endocrinologista \\ do Instituto Nacional do Câncer \\ (INCa), Rio de Janeiro, RJ.
}


numa primeira consulta pode-se fazer o diagnóstico diferencial entre uma metástase cervical, que merece uma investigação mais profunda, e um linfonodo reacional, tão comum em crianças. $\mathrm{O}$ artigo em questão (1) mostra as características de exame físico encontradas nas lesões malignas e que possivelmente direcionaram o diagnóstico.

A punção biópsia por agulha fina guiada por ultrassonografia é hoje um método diagnóstico importante e deve ser utilizado tanto na avaliação do nódulo tireoideano quanto de linfonodos suspeitos. $\mathrm{O}$ pouco valor da punção aspirativa encontrado por Cardoso e cols. em seu artigo (1), talvez seja reflexo do estudo ter sido retrospectivo e não se saber exatamente como foi colhido o esfregaço e a experiência do citopatologista em analisar o material.

$\mathrm{O}$ tratamento com iodo radioativo $\left(\mathrm{Na}^{131} \mathrm{I}\right) \mathrm{em}$ altas doses é considerado seguro, mesmo na população pediátrica. Podem ser administradas atividades de 100 a $200 \mathrm{mCi}$, dependendo da situação do paciente, com intervalos de 6 meses a 1 ano. A incidência de complicações agudas e crônicas é baixa e a resposta terapêutica eficaz, com altos índices de cura. Algumas questões são levantadas em relação o tratamento actínico em crianças: efeito sobre o desenvolvimento puberal, efeitos do hipotireodismo induzido periodiamente (o TSH recombinante ainda não foi liberado com segurança para o uso em crianças), capacidade intelectual futura, possibilidade de ter filhos, indução de menopausa nas adolescentes e aparecimento de outras doenças. A nossa experiência no Instituto Nacional do Câncer (INCa), no acompanhamento de um grupo de 35 crianças com carcinoma diferenciado de tireóide (muitas hoje já são adultas e com uma média de 15 anos de seguimento), é que não há nenhuma interferência do tratamento em qualquer parte do desenvolvimento da criança. Algumas crianças com metástases pulmonares já chegaram a utilizar $900 \mathrm{mCi}$, como mencionado no artigo de Cardoso e cols. (1). A nossa casuística é um pouco diferente da apresentada no artigo em questão. A grande maioria de nossos pacientes apresenta o diagnóstico de carcinoma diferenciado de tireóide (papilífero ou folicular) com metástases ganglionares ou pulmonares. Não temos nenhum caso de carcinoma medular. Todas tiveram desenvolvimento psico-motor adequado, desenvolvimento puberal na época determinada, e muitas já tiveram gestações sem intercorrências. Evidentemente que isto ocorre quando temos crianças em que o diagnóstico é feito ainda em condições de tratamento e não em pacientes que apresentam múltiplas metástases, em geral de tumores pouco diferenciados. Em nosso grupo tivemos, até o momento, apenas um óbito. Tratava-se de uma adolescente de 14 anos com carcinoma insular de tireóide com $1 \mathrm{~cm}$ de diâmetro, que apesar do tratamento (tireoidectomia total e iodo radioativo) evoluiu em 3 anos com metástases ósseas múltiplas, inclusive para órbita, com invasão da meninge. Felizmente, estes casos são raros e a sobrevida da maioria dos pacientes é bem longa, como confirmado em vários estudos da literatura (5). O artigo de Cardoso e cols. (1) mostra casos avançados da doença, diagnosticados tardiamente. Mesmo assim, $9 \mathrm{em} 13$ pacientes $(69 \%)$ com carcinoma diferenciado de tireóide apresentavam-se livre de doença, e os dois óbitos observados não tinham relação direta com a neoplasia tireoideana, mostrando uma melhor evolução dos tumores derivados da célula folicular.

\section{REFERÊNCIAS}

1. Cardoso AA, Pianovski MAD, França SN, Pereira RM, Boguszewski M, Sandrini R, et al. Câncer de tireóide na infância e adolescência: Relato de 15 casos. Arq Bras Endocrinol Metab 2004;48(6):835-841.

2. Kumagai $A$, Namba $H$, Saenko VA, et al. Low frequency of BRAFT1796A mutations in childhood thyroid carcinomas. J Clin Endocrinol Metab 2004;89(9):4280-4.

3. Gydee H, O'Neill JT, Patel A, et al. Differentiated thyroid carcinomas from children and adolescent express IGF1 and IGF-1 receptor (IGFI-R). Cancers with most intense IGFI-R expression may be more aggressive. Pediatr Res 2004;55(4):709-15.

4. Bathia S, Yasui Y, Robison LL, Birch JM, et al. High risk of subsequent neoplasm continues with extended follow up of childhood Hodgkin's disease: report from the Late Effects Study Group. J Clin Oncol 2003;21(23):4386-94.

5. Chow SM, Law SC, Mendhall WM, et al. Differentiated thyroid carcinoma in childhood and adolescence: clinical course and role of radioiodine. Pediatr Blood Cancer 2004;42(2): 176-83.

Endereço para Correspondência:

Rossana Corbo

Av. Canal de Marapendi 2255 - Bloco 1, Apto. 103.

22631-050 Rio de Janeiro, RJ

E-mail: corbo@openlink.com.br 